\title{
BABAD PANJALU \\ (Kajian Struktural, Semiotik, dan Etnopedagogik)
}

\author{
Entoh Toharudin Satibi \\ SMPN 18 Kota Bandung \\ Pos-el: toharudin72@gmail.com
}

\begin{abstract}
Abstrak
Babad Panjalu merupakan salah satu karya sastra kuno yang mengandung unsur sajarah yang ditulis oleh Prajadinata, koleksi C.M. Pleyte. Babad Panjalu menjadi sumber utama dalam penelitian. Penelitian ini menggunakan metode deskriptif yang bertujuan mendeskripsikan struktur babad, unsur semiotik, dan nilai etnopedagogik yang terkandung di dalamnya. Teknik yang digunakan untuk mengumpulkan data yaitu studi bibliografi. Selanjutnya data yang diperoleh diolah menggunakan kajian struktural, semiotik, dan etnopedagogik. Berdasarkan hasil penelitian yang dilakukan, tema sejarah merupakan tema yang terdapat dalam babad ini. Alur maju merupakan pola alur yang digunakan dalam mengembangkan cerita. Pelaku utama yang terdapat dalam cerita yaitu silsilah para bupati Panjalu. Kompleksitas kehidupan, pemikiran, dan persoalan lainnya dikemas dengan dukungan watak yang variatif yang terdapat pada diri para bupati Panjalu. Hal ini didukung oleh digunakanya latar tempat seputar keraton. Kehidupan menak paling mendominasi latar sosial dalam berbagai aspek kehidupan. Dari tiga unsur semiotik yang ditemukan, unsur indéks paling banyak digunakan dari pada unsur ikon dan simbol. Nilai etnopedagogik yang terdapat dalam penelitian ini yaitu nilai moral manusia yang mencakup: moral manusia terhadap Tuhan, moral manusia terhadap pribadi, moral manusia terhadap manusia lain, moral manusia terhadap alam, moral manusia terhadap waktu, dan moral manusia dalam mencapai tujuan hidupnya. Moral manusia terhadap pribadi merupakan nilai moral manusia yang paling banyak terdapat dalam Babad Panjalu.
\end{abstract}

Kata kunci: babad, struktural, semiotik, etnopedagogik

\section{BABAD PANJALU \\ (The Study of Structure, Semiotics, and Ethnopedagogy)}

\begin{abstract}
Babad Panjalu (lit. The Chonicle of Panjalu), which is written by Prajadinata, a collection CM Pleyte, is one of ancient literary works. It contains elements of history. It is the main source in this study. This research used descriptive method that aims to describe the structure, semiotic elements, and the ethnopedagogical values contained in Babad Panjalu. The data collection of this research employed the bibliography study. Afterward, the data was processed by using structural, semiotics, and ethnopedagogy studies. Based on the results of research conducted, the theme of history is contained in this chronicle. Forward plot is the plot pattern that is used in developing the story. The main actors in the story are the Regents of Panjalu, as well as their genealogy. The complexity of life, thoughts, and other problems are packed with the support of varied characters of the Regents of Panjalu. It is sustained by the background of the story that shows the palace and its surrounding. The aristocratic life dominates the social background in various aspects of life. Three semiotic elements were found in the study. The most widely used element is the indexes, above the icons and the symbols. Ethnopedagogical values contained in the chronicle are the human moral values.
\end{abstract}


They include moral toward God, personal, other human being, nature, time, and in achieving goals. The human moral values toward personal is the mostly foind in the Babad Panjalu.

Keywords: babad, structural, semiotics, etnopedagogy

\section{PENDAHULUAN}

Kehidupan karya sastra tergantung kepada lingkungan dan perkembangan jaman yang dilakoninya. Perkembangan sastra dari masa ke masa sudah menunjukan perkembangan yang pesat. Bentuk karya sastra pada jaman dahulu berkembangan dari mulut ke mulut (oral tradition), namun sekarang karya sastra itu sudah dapat dibaca oleh khalayak ramai. Begitu pun jika melihat perkembangan media baik sastra lisan maupun tulisan. Sastra lisan yang terdapat pada masyarakat Sunda di antaranya berupa: carita pantun, dongeng, mantra, kakawihan, pupujian, dan masih banyak lagi. Adapun sastra tulisan berupa naskah dan prasasti yang mempunyai tujuan agar karya tersebut dapat hidup lebih lama serta dikenal masyarakat luas. Di samping itu, dengan adanya karya sastra tulisan terdapat gambaran kehidupan kebudayaan suatu suku bangsa pada masa lampau (lih. Barried, 1985:4).

Koswara (2011:10) menjelaskan bahwa sastra bisa dianggap sebagai gejala sosial yang ditulis pada kurun waktu tertentu yang berhubungan dengan normanorma serta adat-istiadat yang tumbuh pada masa itu. Gejala sosial melahirkan bagaimana deskripsi kehidupan pada jaman itu bisa tampak. Di sisi lain juga sastra itu nggambarkan kehidupan sebagai suatu kenyataan sosial. Hal senada mengenai karya sastra sebagai gambaran kehidupan kebudayaan masa lampau dijelaskan oleh Bachtiar (Ekadjati, 1982:2):

"Karya-karya tulis yang ditinggalkan oleh para nenek moyang ini dapat dipelajari untuk memperoleh gambaran, meskipun tidak lengkap dan tidak menyeluruh, mengenai kebudayaan pada waktu mereka hidup. Pengetahuan yang diperoleh dari karya-karya tulis ini, naskah-naskah ini, dapat membantu kita dalam usaha mempelajari, mengtahui, mengerti, dan kemudian menyajikan sejarah perkembangan bangsa kita."

Karya sastra merupakan salah satu gambaran atau cermin kehidupan (mimetik) dalam kehidupan di masyarakat yang ditampilkan melalui bahasa sebagai medianya. Karya sastra pada prinsipnya mencakup segala kehidupan manusia dalam arti yang luas (lih. Iskandarwassid, 2003:138). Gambaran kehidupan yang ada di masyarakat pada umumnya berdasarkan pada keadaan kehidupan yang dialami sehari-hari. Begitu juga gambaran kehidupan dalam karya sastra dapat ditemukan melalui interaksi sosial yang meliputi berbagai kegiatan komunikasi antarmasyarakat, antarmanusia, dan antarkejadian yang berlangsung. Dengan demikian, kehidupan yang terdapat dalam karya sastra merupakan ungkapan batin secara bebas.

Karya sastra Sunda digunakan untuk menyampaikan berbagai hal yang berhubungan dengan budaya Sunda, sebagai contoh cerita babad. Babad merupakan sejenis cerita masa lampau yang isinya membahas riwayat leluhur atau kejadian penting di suatu daerah, biasanya dimulai dari membuka lahan 'ngababakan' tempat itu (Iskandarwassid, 2003:17).

Mengenai babad, Poerwadarminta (1985:70) menjelaskan bahwa babad sama dengan riwayat, sejarah, atau tambo. Di samping itu, Salmoen (1963:102-103) memasukan cerita babad kepada anak golongan sejarah. Hal itu dikarenakan ada kesamaan berdasarkan kepada unsur sejarah. Akan tetapi, bila dilihat dari segi sejarah dan sastra, babad tetap merupakan karya sastra (Ekadjati, 1982:2). Adapun yang beranggapan menyamakan babad dengan sejarah karena babad merupakan 
sejarah masa lampau pada jamannya. Bahkan ada keterangan bahwa babad umurnya lebih tua dari sejarah (sejarah modern).

Ketidakmurnian unsur sejarah dalam cerita babad dipengaruhi oleh berbagai faktor di antaranya: pengarang, lingkungan, dan tujuan yang ingin dicapai. Faktor pengarang dalam menulis cerita babad sangatlah penting. Keterlibatan pengarang dalam penulisan cerita babad dijelaskan oleh Sumardjo \& Saini KM (1994:24) bahwa walaupun karya sejarah berdasarkan pada beberapa sumber fakta, tapi dalam penyampaiannya tidak lepas dari unsur hayali (imaji) pengarang. Unsur hayali pengarang merupakan salah satu sifat yang ada dalam karya sastra. Hal tersebut dikatakan oleh Ekadjati (1978:1) bahwa:

"Babad menurut pengertian penyusun dan lingkungan masarakatnya dianggap sebangsa sejarah, yaitu tentang masa lampau mereka atau leluhur mereka. Namun demikian kegiatan penyusunan babad tak dapat dilepaskan dari kegiatan penciptaan sastra. Dan babad itu sendiri bila ditinjau dari sudut sastra merupakan karya sastra."

Berdasarkan keterangan di atas, dapat disimpulkan bahwa babad merupakan karya sastra kuno yang mengandung unsur sejarah yang mempunyai tujuan untuk keperluan lingkungan masyarakat tertentu disuatu daerah. Dari pengertian tersebut, babad bisa dijadikan bahan penelitian keilmuan bidang bahasa, sastra, sejarah, antropologi, etnografi, sosiolinguistik, etnopedagogik, dan lain sebagainya.

Media bahasa yang digunakan dalam babad yaitu media tulis, sedangkan bentuk karangannya disampaikan melalui bentuk prosa dan puisi terikat (lih. Ekadjati, spk., 1985:196). Salah satu babad yang menggunakan media tulis dengan bentuk karangan puisi terikat 'pupuh/ wawacan' yaitu Babad Panjalu (BP).
BP merupakan koleksi C.M. Pleyte dari peti no. 121 yang sudah diterbitkan oleh Proyek Penerbitan Buku Sastra Indonesia dan Daerah, Jakarta. Sesuai dengan namanya, BP berasal dari daerah Panjalu, kabupaten Ciamis (priangan). Melihat berasal dari priangan, dengan demikian BP memiliki ciri historiografi priangan yaitu berisikan silsilah raja-raja atau para bupati.

BP merupakan karya sastra tulis yang berdasarkan kepada peristiwa sejarah (sastra sejarah) yang mempunyai nilai etnopedagogik. Nilai etnopedagogik yang terkandung dalam BP akan diketemukan apabila diteliti menggunakan kajian struktural dan semiotik. Kajian struktural mendasarkan penelitian pada struktur cerita sebagai pembangun keutuhan suatu cerita. Struktur cerita menurut Stanton (2012:45) meliputi: tema, fakta cerita, dan sarana sastra. Sedangkan kajian semiotik mencakup unsur: ikon, indéks, dan simbol.

Dilihat dari segi semiotik, BP merupakan sejumlah unsur semiotik yang dapat memberi keterangan masa lampau. Maka dengan demikian, isi BP perlu diteliti melalui kajian semiotik. Cobley dan Litza Janz (Ratna, 2010:97) secara definitif mengatakan bahwa kata semiotik berasal dari bahasa Yunani "seme" yang berarti penafsir tanda. Istilah lainnya "semeion" yang artinya tanda. Tanda yang dimaksud adalah suatu hal yang mewakili tanda/ hal lain (Isnendes, 2010:31). Tanda terdapat dimana-mana, bisa merupakan kecap, gerak isyarat, lampu lalu lintas, dll. Termasuk struktur karya sastra, struktur film, bangunan, atau suara burung bisa dianggap suatu tanda. Berdasarkan pada keterangan tersebut pusat dari penelitian ini adalah menggali struktur babad melalui tema, fakta cerita (alur, pelaku dan watak, dan latar), dan sarana sastra. Selain dari pada itu ketiga unsur semiotik seperti ikon, indeks,dan simbol dibahas dalam penelitian ini. Setelah penelitian dilakukan mendeskripsikan dan menganalisis BP melalui kajian struktur dan semiotik, akan diperoleh nilai 
etnopedagogik yang terkandung di dalamnya.

\section{METODE}

Metode yang digunakan dalam penelitian ini adalah metode deskriptif yang berfungsi untuk menyelesaikan persoalan dalam penelitian (Ratna, 2010:34). Metode deskriptif merupakan metode yang dilakukan untuk mendeskripsikan faktafakta yang selanjutnya dianalisis. Metode deskriptif yaitu metode yang menggambarkan dan memberi pemahaman mengenai fakta-fakta yang terdapat dalam objek penelitian (Ratna, 2010:53). Berdasarkan hal tersebut, metode deskriptif dipilih dikarenakan cerita babad memiliki struktur cerita dan unsur semiotik yang di dalamnya terdapat nilai etnopedagogik. Adapun teknik yang digunakan adalah studi bibliografi yang berfungsi untuk mengumpulkan data yang terdapat dalam BP.

\section{HASIL DAN PEMBAHASAN}

Babad merupakan salah satu karya sastra Sunda kuno 'buhun' yang mengandung unsur sejarah. Sebagai karya sastra, penulisan babad menggunakan bentuk prosa 'lancaran' dan puisi 'kauger'. Baik bentuk prosa maupun bentuk puisi memiliki jalan cerita atau alur yang dapat dianalisis, termasuk BP. Walaupun BP ditulis menggunakan bentuk puisi 'pupuh/ wawacan' tetapi merupakan narasi. Sehingga BP dibangun oleh komponenkomponen atau unsur yang dikenal dengan struktur cerita. Di samping itu, BP mempunyai unsur semiotik dan nilai etnopedagogik yang dapat dijadikan contoh dalam kehidupan sehari-hari dewasa ini.

Struktur cerita yang ada dalam BP mencakup tema, fakta carita (galur, pelaku dan watak, dan latar), dan sarana sastra. Tema suatu cerita tidak dapat diceritakan secara langsung tetapi secara implisit melalui isi cerita secara utuh. Akan tetapi tema dalam BP secara langsung sudah dapat diketahui dari penamaan cerita menggunakan nama babad. Dengan adanya inisial babad, umumnya cerita langsung terpusat pada cerita sejarah masa lalu. Begitu juga tema yang terdapat dalam BP yaitu tema sejarah. Di samping tema sejarah sebagai tema pokok, diketemukan juga subtema pendidikan. Subtema pendidikan terdapat pada pelaku bupati Panjalu dalam usaha mendidik para putranya agar menjadi manusia yang baik sehingga selamat di dunia dan ahirat.

Mengenai alur atau jalan cerita yang terdapat dalam BP menggunakan alur maju 'mérélé'. Hal tersebut dapat dilihat pada episode II samapai dengan episode XXV. Sedangkan episode I dan episode XXVI merupakan permohonan maaf pengarang atas apa yang ditulisnya kepada pembaca. Alur dimulai dengan menceritakan pemerintahan Prabu Borosngora (bupati ke1). Prabu Borosngora memerintah sebagai bupati Panjalu. Selanjutnya Prabu Borosngora sekeluarga pindah ke Jampang (épisode II nepi ka IV).

Radén Arya Kuning (bupati ke-2) memerintah jadi bupati Panjalu menggantikan orang tuanya. Terjadi perselisihan antara kakak beradik (épisode $\mathrm{V}$ nepi ka VII). Perselisihan dapat didamaikan setelah Raden Kampuh Jaya sebagai perwakilan Prabu Borosngora datang ke Panjalu. R. Kampuh Jaya menyelesaikan perseteruan kakak beradik dengan arif dan bijaksana. Putra yang unggul dalam perkelahian itu dijadikan bupati di Panjalu, yaitu R.A. Kancana. Selanjutnya R.A. Kuning dibawa ke Jampang oleh R. Kampuh Jaya (épisode VIII).

Pemerintahan Panjalu dipegang oleh R. Arya Kancana (bupati ke-3) yang terdapat pada episode IX. Sebagai patihnya yaitu Raden Kampuh Jaya yang berganti nama menjadi R. Guru Haji (episode X dan XII). Pada masa pemerintahan R. Arya Kancana, daerah Panjalu semakin makmur dan sejahtera. Selama memerintah, R. Arya Kancana memiliki banyak anak, salah seorangnya bernama Sanghyang Teko. 
Raden Arya Kancana pensiun dari jabatannya dan digantikan oleh putranya yang pertama, Sanghyang Teko (episode XIII).

Alur selanjutnya, pemerintahan Sanghyang Teko (bupati ke-4). Sanghyang Teko memiliki dua orang putra, Raden Dulang Kancana dan Raden Kadaliru. Dikarenakan Sanghyang Teko wapat, pemerintahan dilanjutkan oleh putranya yang pertama, R. Dulang Kancana (episode XIV).

Raden Dulang Kancana (bupati ke-5) memerintah di Panjalu menggantikan orang tuanya. Raden Dulang Kancana tidak lama menjabat sebagai bupati Panjalu dikarenakan meninggal. Selama memerintah R. Dulang Kancana tidak diceritakan memiliki putra. Dengan demikian pemerintahan dilanjutkan oleh adiknya, Raden Kadaliru (episode XV). Raden Kadaliru (bupati ke-6) memiliki putra Raden Martabaya. Dikisahkan Raden Kadaliru wapat, lalu jabatan bupati Panjalu dilanjutkan oleh anaknya, Raden Martabaya (episode XVI).

Raden Martabaya (bupati ke-7) menjabat bupati Panjalu menggantikan orang tuanya, Raden Kadaliru. Raden Martabaya memiliki putra yang bernama Raden Arya Natibaya. Dikarenakan Raden Martabaya wapat, pemerintahan dilanjutkan oleh putranya, Raden Arya Natibaya (episode XVII).

Raden Arya Natibaya (bupati ke-8) sebagai bupati Panjalu melanjutkan orang tuanya. Raden Arya Natibaya mempunyai dua orang putra, Dalem Sumalah dan Radén Arya Sacanata. Dikarenakan Raden Arya Natibaya wapat, pemerintahan dijabat oleh anaknya yang pertama, Dalem Sumalah (episode XVIII). Dalem Sumalah (bupati ke-9) mempunyai putra yang masih kecil, Raden Wirabaya. Pemerintahan Dalem Sumalah tidak begitu lama dikarenakan meninggal dunia. Selanjutnya pemerintahan dijabat oleh adiknya Dalem Sumalah, Raden Arya Sacanata (episode XIX).
Raden Arya Sacanata (bupati ke-10) pada saat menjabat bupati Panjalu terbilang sudah agak tua 'sepuh'. Raden Arya Sacanata memiliki anak yang masih kecil, Raden Wiradipa. Karena sudah merasa tua, pemerintahan diserahkan kepada anak kakanya, Raden Wirabaya (putra Dalem Sumalah). Pada episode XX dijelaskan bahwa Raden Wiradipa, putranya Raden Arya Sacanata dipelihara oleh Raden Wirabaya yang menjabat bupati saat itu.

Raden Wirabaya (bupati ke-11) menjabat bupati Panjalu menggantikan Raden Arya Sacanata, pamannya. Raden Wirabaya mempunyai anak yang bernama Raden Wirapraja. Raden Wirabaya wapat, jabatan bupati dilanjutkan oleh anaknya, Raden Wirapraja (episode XXI).

Raden Wirapraja (bupati ke-12) menggantikan ayahnya menjadi bupati Panjalu. Selama menjadi bupati Raden Wirapraja tidak diceritakan mempunyai anak. Cerita diseling dengan mengisahkan putranya Raden Arya Sacanata, Raden Wiradipa. Raden Wiradipa memiliki anak yang bernama Raden Cakranagara. Sebelum Raden Wirapraja selesai menjabat bupati, dia meninggal dunia. Selanjutnya pemerintahan diteruskan oleh saudaranya, Raden Cakranagara (episode XXII).

Raden Cakranagara (bupati ke-13) sebagai bupati Panjalu menggantikan Raden Wirapraja. Raden Cakranagara memiliki putra yang bernama Raden Cakranagara 'kapindo' (Raden Cakranagara II). Raden Cakranagara wapat, jabatan bupati dilanjutkan oleh putranya, Raden Cakranagara II (episode XXIII).

Raden Cakranagara II (bupati ke-14) menjabat bupati Panjalu menggantikan orang tuanya, Raden Cakranagara. Raden Cakranagara II rajin mencari ilmu khususnya ilmu agama sampai ke Cirebon. Raden Cakranagara II mempunyai istri kemenakanya Sultan Cirebon yang bernama Raden Salengga Anom. Dari pernikahannya, Raden Cakranagara II memiliki anak yang bernama Raden Barsalam. Raden Cakranagara II wapat, 
jabatan bupati dilanjutkan oleh putranya, Radén Barsalam. Selanjutnya Raden Baralam berganti nama menjadi Raden Cakranagara Anom (episode XXIV).

Raden Cakranagara Anom (bupati ke15) merupakan bupati Panjalu yang terakhir, dikarenakan beliau dipensiun lantaran anjeunna dipangsiun pada tahun 1819 M oleh Sultan Cirebon. Raden Cakranagara Anom menjabat bupati Panjalu selama 33 tahun. Pada akhir pemerinahan Raden Cakranagara Anom, Kabupaten Panjalu berubah menjadi kawedanaan serta disatukan kepada Kabupaten Galuh (episode XXV).

Pelaku yang terdapat dalam BP terpusat kepada pelaku sentral para bupati yang memiliki kedudukan penting dan strategis di daerah Panjalu. Pelaku yang terbilang penting: Prabu Borosngora, R.A. Kuning, R.A. Kancana, Sanghyang Téko, R. Dulang Kancana, R. Kadaliru, R.Martabaya, R.A. Natibaya, Dalem Sumalah, R.A. Sacanata, R. Wirabaya, R. Wirapraja, R. Cakranagara, R. Cakranagara II, dan R. Cakranagara Anom. Pelaku yang terbilang penting lainnya yaitu patih Panjalu, R. Guru Haji (R. Kampuh Jaya). Di samping itu terdapat beberapa orang pelaku yang diketemukan pada BP seperti: Otek, Ki Buni Sakti, Kojal, Kodal, Raden Wiradipa (ramana R. Cakranagara), Ki Malim, Sultan Cirebon, Raden Salengga Anom (istrinya R. Cakranagara Anom), masyarakat Panjalu, dan masyarakat Jampang. Pelaku yang ada dalam BP mempunyai watak yang baik dan dijadikan panutan karena jabatan pelaku utama sebagai orang penting sebagai pelaku bupati. Watak yang terbilang paling baik ada pada pelaku Prabu Borosngora sebagai bupati Panjalu yang pertama beragama Islam. Pelaku kedua adalah R. Cakranagara Anom, sebagai bupati terakhir. Karakter R. Cakranagara Anom terlihat pada episode XXV ketika dia menasehati, mendidik, dan mengajar para putranya yang jumlahnya banyak.
Latar yang terdapat dalam BP meliputi tempat, waktu dan sosial. Latar tempat umumnya merupakan nama wilayah/ daerah yang sampai sekarang masih digunakan. Latar tempat yang terdapat di seputar Panjalu di antaranya: Maparah, Panjalu, Situ Léngkong, Cukang Padung, Nusa Pakél, Ujung (Hujung) Winangun, Sindangrame, Ciluncat, Pecat Obol, Cinarakal, Cinarakas, Sukatingal, Cibutut, Cieunteung, Hanjatan, Dukuh Munar, Ranca Beureum, Nusa Sireum, Cilanglung, Gandakerta, Warganaya, Ciater, Winarni, dan Sumalah. Sedangkan latar tempat yang berada di luar daerah Panjalu yaitu: Jampang, Sukapura, Malangbong, Warudoyong, Galuh (Ciamis), Kandangwesi, Gunung Walahar, Citanduy, Priangan, Gajipura, Cirebon, Kalipucang, Banjar, dan Kawali. Selain itu ada beberapa tempat yang digunakan sebagai latar di antaranya: padaleman, karaton/ kadaton, astanal makam, dapur, alun-alun, pasir, patapaan, imah, leuweung, tempat, pancaniti, sawah, tanah, bumi mantri, bumi patih, paimahan, paséban, pinggir cai, tambakan, di darat, di cai, saung, pasanggrahan, tebéh hilir, kapatihan, jalan, $d s b$.

Waktu yang dijadikan latar dalam BP pada umumnya merupakan bilangan titimangsa yang berkaitan erat dengan diri pengarang. Pengarang (R. Prajadinata) termasuk salah seorang putra $\mathrm{R}$. Cakranagara Anom. Dengan demikian, waktu yang digunakan seputar keraton dan mendapatkan cerita langsung dari orang tuanya (R. Cakranagara Anom). Mengenai latar waktu yang diketemukan dalam BP, seperti: (1) wewerat geus tilu sasih, (2) tujuh poé tujuh peuting, (3) tahun séwu tujuh ratus, genep puluh lima deui, (4) dina yuswa dua puluh opat tahun, (5) Kaleresan tahun séwu dlapan ratus, salapan welas nu muni, (6) tilu puluh tahun yaktos, (7) dina yuswa saratus tahun téh, séwu dlapan ratus lima puluh hiji, (8) tilu tahun lamina téh, (9) nembe umur dua welas warsih, (10) nuju umur tilu puluh warsih, (11) tahun 
séwu dlapan ratus leuwih, tahun anu yaktos, jeung sawidak dalapan nu nyandé, dan (12) tilu puluh dalapan teu géséh. Selain itu, terdapat pula waktu yang berhubungan dengan mengolah cerita, seperti: (1) teu lami waktuna deui. (BP, 1982:25/8), (2) Nyarioskeun nu baheula, (BP, 1982:25/12), (3) Bukti dungkap ka ayeuna, (BP, 1982:27/23), (4) Poé isuk badé ngalih, (BP, 1982:38/65), (5) Mana nelah ka kiwari, (BP, 1982:48:106), dan (6) Siang wengi sami kumpul, (BP, 1982:123/483).

Latar sosial yang terdapat dalam BP merupakan latar yang erat hubungannya dengan ststus sosial yang terdapat di daerah Panjalu. Adanya padaleman dan keraton menandakan kehidupan masa lampau. Berdasarkan keterangan tersebut, jelas nampak adanya status sosial yang sangat jauh (feodalisme). Adanya bupati lengkap dengan pengikutnya 'abdi dalem' dengan masyarakat Panjalu pada umumnya. Manutnya abdi dalem dan rakyat kepada pemimpinnya menunjukan betapa pentingnya kekuasaan pemimpin dalam rangka mensejahterakan rakyat. Maju mundurnya suatu pemerintahan dapat dilihat dari gambaran kesejahteraan masyarakatnya. Terampil atau tidaknya pengarang dalam mendeskripsikan kesejahteraan rakyat dengan bupatinya tergantung kepada keterampilan dan pengetahuan pengarang. Pada BP juga tampak peran bupati sebagai status sosial kelas 'atas' dengan masyarakat pendukungnya sebagai kelas 'bawah'.

BP ditulis dalam bentuk wawacan, namun untuk memaknai unsur semiotik yang dimilikinya terbilang lumayan. Unsur semiotik meliputi tiga bagian yakni ikon, indeks, dan simbol. Unsur semiotik yang terdapat dalam BP komposisinya tidak seimbang tergantung data yang ditemukan.

Indeks merupakan unsur semiotik yang terbilang banyak diketemukan dibanding unsur semiotik lainya. Indeks yang diketemukan ada 142 référént, meliputi: (1) kasmaran, (2) ngarang, (3) rama, (4) bisluit, (5) raja, (6) kahadéan, (7) ujang, (8) kolot, (9) sembah sujud, (10) ngangluh, (11) ka kalanggengan, (12) putra, (13) nya ieu, (14) sim kuring, (15) nyarioskeun, (16) ngabangun, (17) ningalan, (18) pinggir cai, (19) unggal poé unggal peuting, (20) ngajaga, (21) gilig jeung prakasa, (22) pameget, (23) ngaheurap, (24) ngubeng, (25) sampan parahu, (26) gagah, (27) salira, (28) pelesiran, (29) pepelakan, (30) ngadamel, (31) ameng-amengan, (32) saban siang, (33) di dinya, (34) diajar, (35) tempat ieu, (36) kapatihan, (37) paséban, (38) palataran, (39) pasrah, (40) ngalahir, (41) sepuh, (42) patih, (43) ti dinya, (44) kahartos, (45) unjukan, (46) ngistrénan, (47) gagancangan, (48) $\mathrm{ka}$ dieu, (49) hurung, (50) ngaguruh, (51) éar, (52) melas-melis, (53) ngadawuh, (54) nyeri hulu, (55) marunjungan, (56) ajrih, (57) ngelas ati, (58) dipimanah, (59) maphum, (60) raresik, (61) binangkit berbudi, (62) nangis, (63) ngawawaas, (64) akang, (65) heurin usik, (66) singkil, (67) lahir batin, (68) ariyatna, (69) adil, (70) senang ati, (71) raos galih, (72) leumpang gancang, (73) ngarérét, (74) kagét, (75) sajero penggalih, (76) manéh, (77) ti heula, (78) gura-giru, (79) gadag-gidig, (80) pandeuri, (81) rai, (82) cékcok, (83) nyair, (84) resmi galih, (85) aing, (86) aki, (87) kacuwa, (88) ngaleut, (89) raka, (90) teu éling, (91) patubruk, (92) wiwirang, (93) tiris, (94) hanjat, (95) sidéang, (96) badami, (97) ngejat, (98) kaduhung, (99) luncat, (100) pundung, (101) kapikir, (102) mébérkeun ramo, (103) waspada, (104) ngeduk taneuh, (105) géhgér, (106) rusuh, (107) tonggoy, (108) ruménghap, (109) bendu, (110) jahil, (111) susumbar, (112) reup geuneuk, (113) ngadangukeun, (114) miris, (115) ka tepiswiring, (116) ngangres, (117) nyengka, (118) méré tanggara, (119) amarah, (120) kanyeri, (121) geder, (122) tarampil, (123) percaya, (124) nyapih, (125) kalangsu, (126) kapanasan, (127) nyuuh, (128) palid, (129) dingin, (130) sumeblak, (131) ngésod, (132) kamelang, (133) bingah, (134) 
katumbiri, (135) ngalayad, (136) yuswa geus ahir, (137) kula, (138) burudul, (139) jedur mariemna, (140) murangkalih, (141) ngaregepkeun, dan (142) jaman baheula.

Indeks yang berhubungan dengan tipe rengkak paripolah menduduki urutan tipe paling atas berdasarkan jumlah referent yang diketemukan. Tipe réngkak paripolah jumlahnya ada 48 référént: (1) ngarang, (2) kahadéan, (3) sembah sujud, (4) nyarioskeun, (5) ngabangun, (6) ngajaga, (7) ngaheurap, (8) ngubeng, (9) pelesiran, (10) pepelakan, (11) ngadamel, (12) ameng-amengan, (13) diajar, (14) ngalahir, (15) ngistrénan, (16) gagancangan, (17) ngadawuh, (18) marunjungan, (19) nangis, (20) heurin usik, (21) singkil, (22) leumpang gancang, (23) ngarérét, (24) gura-giru, (25) gadag-gidig, (26) nyair, (27) ngaleut, (28) patubruk, (29) hanjat, (30) sidéang, (31) badami, (32) ngejat, (33) luncat, (34) mébérkeun ramo, (35) ngeduk taneuh, (36) rusuh, (37) tonggoy, (38) ruménghap, (39) susumbar, (40) ngadangukeun, (41) méré tanggara, (42) tarampil, (43) nyapih, (44) nyuuh, (45) ngésod, (46) ngalayad, (47) burudul, dan (48) ngaregepkeun.

Indeks yang berhubungan dengan tipe gejala fisik ada 47 référént: (1) kasmaran, (2) ngangluh, (3) ningalan, (4) gilig jeung prakasa, (5) gagah, (6) salira, (7) pasrah, (8) kahartos, (9) unjukan, (10) nyeri hulu, (11) ajrih, (12) ngelas ati, (13) dipimanah, (14) maphum, (15) binangkit berbudi, (16) ngawawaas, (17) lahir batin, (18) ariyatna, (19) adil, (20) senang ati, (21) raos galih, (22) kagét, (23) sajero penggalih, (24) resmi galih, (25) kacuwa, (26) teu éling, (27) wiwirang, (28) tiris, (29) kaduhung, (30) pundung, (31) kapikir, (32) waspada, (33) bendu, (34) jahil, (35) reup geuneuk, (36) miris, (37) ngangres, (38) nyengka, (39) amarah, (40) kanyeri, (41) percaya, (42) kalangsu, (45) sumeblak, (46) kamelang, dan (47) bingah.

Indeks yang memiliki tipe aktualisasi terdapat 34 référént: (1) rama, (2) bisluit, (3) raja, (4) ujang, (5) kolot, (6) ka kalanggengan, (7) putra, (8) nya ieu, (9) sim kuring, (10) pinggir cai, (11) pameget, (12) saban siang, (13) di dinya, (14) tempat ieu, (15) kapatihan, (16) paséban, (17) palataran, (18) sepuh, (19) patih, (20) ti dinya, (21) ka dieu, (22) akang, (23) manéh, (24) ti heula, (25) pandeuri, (26) rai, (27) aing, (28) aki, (29) raka, (30) ka tepiswiring, (31) yuswa geus ahir, (32) kula, (33) murangkalih, dan (34) jaman baheula.

Indeks yang berhubungan dengan tipe sora ada 7 référént meliputi: (1) ngaguruh, (2) éar, (3) melas-melis, (4) cékcok, (5) géhgér, (6) geder, dan (7) jedur mariemna. Sedangkan indeks yang berhubungan dengan barang atau zat ada 4 référént yaitu: (1) sampan parahu, (2) hurung, (3) kapanasan, jeung (4) dingin. Di samping itu, indeks yang memiliki tipe gejala alam ada 3 référént: (1) unggal poé unggal peuting, (2) raresik, dan (3) katumbiri.

Ikon merupakan unsur semiotik kedua berdasarkan jumlah data yang diketemukan. Ada 17 référént ikon yang terdapat dalam BP meliputi: (1) tanah pusaka, (2) parentul hurung, (3) dihin pinasti, (4) titis tulis, (5) ieu poé ngabungsuan, (6) neukteuk curuk dina pingping, (7) ngaleut ngeungkeuy pababantay, (8) bancang pakéwuh, (9) kaduhung tara ti heula, (10) ngalahir jeung manis, (11) ka darat jadi salebak, (12) ka cai jadi saleuwi, (13) kotok meuting, (14) ati, (15) jajantung, (16) budi manis, dan (17) wewerat. Dari sejumlah ikon yang diketemukan terbagi lagi menjadi 3 tipe. Tipe imagis ada 3 référént yakni: (1) ati, (2) jajantung, dan (3) wewerat. Tipe metaforis ada 14 référént yaitu: (1) tanah pusaka, (2) parentul hurung, (3) dihin pinasti, (4) titis tulis, (5) ieu poé ngabungsuan, (6) neukteuk curuk dina pingping, (7) ngaleut ngeungkeuy pababantay, (8) bancang pakéwuh, (9) kaduhung tara ti heula, (10) ngalahir jeung manis, (11) ka darat jadi salebak, (12) ka cai jadi saleuwi, (13) kotok meuting, dan (14) budi manis. Tipe diagramatis tidak terdapat dalam BP.

Simbol merupakan unsur semiotik 
ketiga berdasarkan jumlah référén yang diketemukan. Unsur simbol yang terdapat dalam BP jumlahnya ada 8 référént, mencakup: (1) karaton, (2) bérok, (3) emas, (4) duit, (5) pedang, encit, locéng, jeung kuluk, (6) kuda, sapi, jeung munding, (7) umbul-umbul, dan (8) medali. Simbol yang disebutkan di atas merupakan tanda yang sudah tidak asing lagi di telinga masyarakat Panjalu. Melalui simbol tersebut dapat dilihat bagaimana keadaan ekonomi, sosial, dan kedudukan seseorang di masyarakat.

Nilai etnopedagogik yang menjadi bahasan mencakup nilai moral manusia. Nilai moral manusia yang ada dalam BP erat kaitannya dengan pelaku para bupati yang terdapat di Panjalu. Nilai moral manusia meliputi: (1) moral manusia terhadap Tuhan (MMT), (2) moral manusia terhadap dirinya (MMD), (3) moral manusia terhadap manusia lainnya (MML), (4) moral manusia terhadap alam (MMA), (5) moral manusia terhadap waktu (MMW), dan (6) moral manusia dalam mencapai tujuan hidup (MMTH).

Secara kuantitas jumlah keenam nilai etnopedagogik yang diketemukan dalam BP tidaklah seimbang. Nilai etnopedagogik yang dianggap paling dominan kuantitasnya terdapat pada nilai moral manusia terhadap dirinya (MMD) sekitar $40 \%$ (episode II sampai XXV). Moral manusia terhadap dirinya merupakan sikap manusia yang berhubungan dengan manusia sebagai individu/pribadi yang ditandai dengan kualitas sumber daya manusia dalam bertindak. Hal tersebut tampak pada pelaku para bupati Panjalu dalam melakukan perbuatan pada setiap tatanan kehidupan baik secara pribadi maupun secara komunal.

Nilai moral manusia terhadap dirinya yang terbilang kerap muncul dalam cerita yaitu pada pelaku Prabu Borosngora, Radén Arya Kuning, Radén Arya Kancana, dan Radén Kampuh Jaya (patih Panjalu). Hal tersebut bukan berarti nilai moral manusia yang lainnya tidak penting. Nilai moral manusia menunjukan betapa manusia sebagai pelaku dalam kehidupan harus berpikir panjang lebar, baik buruk, boleh tidak, dll. Namun bagaimanapun tindakan tersebut semuanya menggambarkan bagaimana seorang pelaku dalam BP mendewasakan dirinya.

Berdasarkan data yang ditemukan dalam BP, nilai moral manusia terhadap dirinya ditandai dengan sipat yang baik antara lain: (1) sopan, (2) sederhana 'basajan', (3) jujur, (4) berani, (5) dapat dipercaya, (6) menghargai orang lain, (7) waspada 'iatna', (8) bisa mengendalikan diri, (9) adil, (10) mencintai tanah air, (11) baik hati (12) teguh pendirian, dan (13) memiliki pandangan yang luas.

Moral manusia terhadap Tuhan (MMT) yang terdapat dalam BP kurang lebih ada 30\%. MMT menggambarkan sikap dan prilaku para bupati yang taat menjalankan perintah agama dalam kehidupan sehari-hari. Nilai moral manusia terhadap Tuhan bersipat religius yang erat kaitanya dengan ketakwaan. Hal tersebut dapat dilihat bagaimana para bupati Panjalu dalam melakukan suatu pekerjaan baik dari ucapan maupun tindakan. Yang paling tampak religius yaitu pelaku Prabu Borosngora sebagai penyebar agama Islam pertama di daerah Panjalu. Selanjutnya pelaku Raden Cakranagara II yang menuntut ilmu agama ke daerah Cirebon yang pada akhirnya meminang keponakan Sultan Cirebon yang bernana Raden Salengga Anom. Begitu juga pelaku yang bernama Raden Cakranagara Anom (Raden Barsalam) yang mengikuti jejak leluhurnya, Prabu Borosngora yang agamis. Raden Cakranagara Anom mendidik para putranya dengan ilmu agama yang berguna untuk keselamatan dunia dan akhirat. Di samping itu juga diketemukan adanya prilaku eling ka pangeran, upamanya pelaku para bupati, diantaranya pelaku R.A. Kuning dalam ucapannya selalu menyebut Allah seperti astagfirullah, bissmillah, dll.

Nilai moral manusia dalam mencapai tujuan hidup (MMTH) yang terdapat dalam BP kurang lebih 10\%. MMTH memiliki tujuan untuk mendapatkan ketentraman 
hidup lahir batin. Dalam mencapai ketentraman hidup, para bupati selalu berprinsip sineger tengah antara kepentingan dunia dan akhirat. Nilai MMTH juga terdapat pada pemenuhan kebutuhan hidup seperti ingin membahagiakan masarakat Panjalu dengan cara membedah Situ Lengkong. Pada dasarnya nilai MMTH bukan saja untuk dirinya sendiri maelainkan juga dapat dilakukan terhadap kebahagian orang lain. Apabila tujuan hidup orang lain sudah terpenuhi maka dengan sendirinya nilai MMTH orang yang bersangkutan merasa sudah tercapai.

Nilai moral manusia terhadap alam (MMA) yang terdapat dalam BP kurang leuwih 10\%. MMA dapat diketahui melalui prilaku para pelaku / bupati dalam menghadapi alam secara bijaksana dengan prinsip alam yang didiami merupakan pinjaman dari generasi yang akan datang. Jadi, sudah selayaknya manusia menjaga pinjaman ini agar tetap lestari tanpa merusaknya. Para bupati dan masarakat Panjalu dalam mengelola alam untuk kesejahteraan bersama sangatlah terampil. Nilai moral inilah yang menjadi landasan dalam menjaga kelestarian ekologi.

Nilai moral manusia terhadap manusia lainnya (MML) yang terdapat dalam frekuensinya kurang lebih BP 5\%. MML dapat diketahui dalam kehidupan seharihari. Manusia di samping mahluk individu juga makhluk sosial yang banyak berhubungan dengan manusia lainnya. Bagaimana nilai MML tampak pada komunikasi yang santun antara pelaku bupati dengan bawahannya termasukdengan masyarakat Panjalu. Pelaku yang mempunyai kepribadian baik dapat terlihat dari tutr katanya, begitu juga sebaliknya. Nilai MML dilandasi oleh sikap saling menghargai/ toleransi, saling percaya, saling menasihati, saling membutuhkan, dll. bahwa manusia (masyarakat Panjalu) adalah satu kesatuan yang utuh sebagai bagian dari suatu bangsa.
Nilai manusia terhadap waktu (MMW) yang terdapat dalam BP frekuensinya kurang lebih 5\%. MMW dapat diketahui melalui pelaku para bupati dalam memanfaatkan waktu untuk kepentingan bersama. Di samping itu, percaya terhadap ketentuan Yang Maha Kuasa 'papasten' dalam kehidupan. Adanya kehidupan yang abadi/ langgeng di akhirat kelak merupakan suatu kehidupan dipengaruhi oleh amalan kehidupan di dunia. Begitu juga adanya proses kelahiran sampai kematian sebagai siklus atau daur hidup manusia. Kesemuanya merupakan ketentuan yang harus disikapi dengan arif. Sehingga manusia dapat memanfaatkan waktu dengan hal-hal yang positif semata-mata untuk kepentingan orang banyak. Para bupati Panjalu setidaknya melangkah dengan prinsip di atas. Adapula pelaku bupati yang memanfaatkan waktu dengan mendidik dan mengajar para putranya sebagaimana yang dicontohkan oeh pelaku Raden Cakranagara Anom setelah pensiun dari bupati.

Nilai moral manusia yang terdapat dalam BP merupakan salah satu kearifan lokal yang dimiliki oleh masyarakat Panjalu/ Sunda yang harus dipelihara dan dilestarikan. Hal tersebut, karena nilai etnopedagogik yang terdapat dalam BP masih relevan sampai sekarang. Sehingga, perlu adanya upaya untuk mentransper nilai etnopedagogik Sunda kepada generasi yang akan datang untuk membangun jati diri bangsa yang berkarakter. Upaya tersebut tentunya melalui dunia pendidikan baik sekolah maupun perguruan tinggi.

\section{SIMPULAN}

BP merupakan salah satu buku karya sastra yang diterbitkan oleh Departemen Pendidikan dan Kebudayaan. BP ditulis menggunakan bentuk puisi terikat 'wawacan', yang di dalamnya merupakan suatu cerita. Suatu karya sastra tentu memiliki struktur cerita. Struktur cerita yang terdapat dalam BP pada dasarnya mencakup kesatuan unsur atau komponen yang saling berkaitan. 
Sesuai dengan namanya, BP bertemakan sajarah. Di dalamnya terdapat kisah yang ditampilkan dengan jalan cerita/ alur silsilah para bupati Panjalu dari masa pemerintahan Prabu Borosngora (bupati ke1) sampai dengan Raden Cakranagara Anom (bupati ke-15). Di samping itu, terdapat pula subtema atikan dalam BP.

Alur yang menjadi ciri khas BP menggunakan alur maju 'mérélé'. Hal tersebut dapat dilihat dari peristiwa dan pelaku yang dipisahkan menurut episode. Episode BP terbagi menjadi 26 episode dengan 1 episode awal sebagai permohonan maaf pengarang dan 1 episode terakhir jug merupakan permohonan atas ketunaan dalam mengarang BP. Jadi, inti ceritanya terdapat pada episode II samapai XXV. Unsur pelaku, paling dominan tampak dalam BP sebagai karya sastra ciri khas babad, dimana adanya kematian, pelantikan bupati baru, jasa selama jadi bupati, peristiwa yang fenomenal, dll. Tercatat ada sekitar 15 bupati yang memerintah di daerah Panjalu. Yang selanjutnya daerah Panjalu jadi kawedanaan (di atas setingkat kecamatan) dan di satukan ke Kabupaten Galuh (Ciamis sekarang). Adapun latar tempat yang digunakan latar dalam BP terbilang paling dominan frekuensinya. Tempat tersebut berada di sekitar daerah Panjalu dan luar Panjalu. Tempat tersebut sampai saat ini masih diketemukan. Sedangkan latar sosial diketemukan dengan adanya ststus sosial dalam kehidupan kebupatian antara bupati dan masarakatnya 'abdi' pada masa lalu.

Unsur indeks merupakan unsur yang menggambarkan adanya hubungan kausalitas dari tanda dalam BP. Unsur indeks yang terdapat dalam BP jumlahnya menduduki peringkat pertama dari semiotik dengan jumlah 142 referent. Diikuti oleh unsur ikon dengan jumlah 17 referent dan unsur simbol sebanyak 8 referent.

Nilai 'ajén' etnopedagogik yang terdapat dalam BP meliputi nilai moral manusia. Nilai moral manusia yang ada dalam BP erat kaitannya dengan pelaku para bupati yang terdapat di Panjalu sebagai panutan. Nilai moral manusia diurutkan berdasarkan frekuensi data yang diketemukan, meliputi: (1) moral manusia terhadap dirinya (MMD) sekitar 40\%, (2) moral manusia terhadap Tuhan (MMT) sekitar 30\%, (3) moral manusia dalam mencapai tujuan hidup (MMTH) sekitar $10 \%$, (4) moral manusia terhadap alam (MMA) sekitar 10\%, (5) moral manusia terhadap manusia lainnya (MML) sekitar $5 \%$, dan (6) moral manusia terhadap waktu (MMW) sekitar 5\%.

Karya sastra golongan babad (Babad Panjalu) merupakan karyasastra klasik yang mengandung nilai kearifan lokal yang tinggi. Diperlukan penelitian yang lebih komprehensif untuk mengungkap berbagai fenomena yang ada di dalamnya. Selanjutnya, hasil penelitian dari perguruan tinggi dicetak menjadi buku agar khalayak bisa mengetahuinya. Sehingga nilai yang terkandung di dalamnya dapat dijadikan sebagai bahan ajar nilai karakter bangsa yang berjati diri yang memiliki kepribadian bangsa yang kuat.

\section{PUSTAKA RUJUKAN}

Barried, Baroroh. 1985. Pengantar Teori Filologi. Jakarta: Pusat Pembinaan dan Pengembangan Bahasa.

Ekadjati, Edi S. 1978. Babad (Suatu Karya Sastra Sejarah). Bandung: Lembaga Kebudayaan UNPAD.

Ekadjati, Edi S. 1982. Cerita Dipati Ukur; Karya Sastra Sejarah Sunda. Jakarta: Pustaka Jaya.

Ekadjati, Edi S., spk. 1985. Naskah Sunda Lama Kelompok Babad. Jakarta: Pusat Pembinaandan Pengembangan Bahasa.

Iskandarwassid. 2003. Kamus Istilah Sastra. Bandung: Geger Sunten.

Koswara, Dedi. 2011. Racikan Sastra. Bandung: Jurusan Pendidikan Bahasa Daerah FPBS UPI. 
Poerwadarminta, W.J.S. 1985. Kamus Besar Bahasa Indonesia. Jakarta: Balai Pustaka.

Ratna, Nyoman Kutha. 2010. Teori, Metode, dan Teknik Penelitian Sastra dari Strukturalisme hingga Poststrukturalisme. Yogyakarta: Pustaka Pelajar.

Salmoen, M.A. 1963. Kandaga Kasusastraan Sunda. Bandung: Ganaco.

Stanton, R. 2012. Teori Fiksi Robert Stanton. Yogyakarta: Pustaka Pelajar.
Sumardjo, Jakob \& Saini K.M. 1994. Apresiasi Kesusastraan. Jakarta: Gramedia.

\section{UCAPAN TERIMA KASIH}

Ucapan terima kasih yang sebesarbesarnya saya sampaikan kepada semua pihak yang membantu penelitian ini, terimakasih pula kepada pembimbing tesis, dan kepada penyunting Jurnal Lokabasa yang berkenan memuat tulisan ini penulis mengucapkan terima kasih. 